\title{
COMPULSORY ATTENDANCE AT SCHOOL
}

\author{
Charles $\mathrm{K}$. Woltz*
}

I

We find ourselves in this country in the happy situation where attendance at school by the vast majority of children of school age is a fact accepted as normal by everyone, and as proper by all except a few restless ones among the children and a few eccentric ones among the parents. For the school year 1949-I950 (the last year covered by the biennial survey of the Federal Office of Education) some 25,4ri;000 pupils were enrolled in public elementary and secondary schools and an additional 3,380,139 in private and parochial schools. They represented over 9I per cent of the nation's 5-17 year olds. These children were not merely enrolled in school; they came, which is more to the point. For 1949-1950 average daily attendance in the public schools was reported at 88.7 per cent. ${ }^{1}$ With only slight variations in individual states, these percentages held true throughout the country and for all classes of the population. Current figures, if available, would undoubtedly present totals no less pleasing to the educator's eye. In short, we are at a point where no one questions the obligation of the state to make education available to all its citizens, where parents realize and voluntarily discharge their duty to send their children to school, and where the children either go willingly or submit without too much fuss to parental and social pressure.

To disturb contemplation of this fortunate condition by a discussion of compulsory attendance laws might seem not only ungracious but unnecessary. And it is true that no one claims for such laws chief credit for the present favorable record of enrollment and attendance. ${ }^{2}$ But things were not always as they now are in this matter of going to school, and the coercion of the law has had no inconsiderable part in producing the change for the better. More pertinent perhaps, attitudes toward school attendance will not continue to be the same in those states where preponderant public opinion finds distasteful the legal and sociological views expressed in Brown v. Board of Education. ${ }^{3}$ Assuming as I think one can at this time that the states whose practices are affected by that decision will continue their systems of public free schools, they may continue or may repeal their compulsory attendance laws. Where such laws are left on the books, local officials may enforce

* B.A. I934, LL.B. 1937, University of Virginia. Member of the Virginia bar; Associate Professor of Law, University of Virginia, 1947-1952; Professor of Law since 195\%.

1 Biennial SuRvey of Education IN The United States, 1948-1950, c. 2, Statistics of State School Systems (U.S. Office of Education, 1952).

" "Stricter, and more practical enforcement of the compulsory attendance laws" is placed sixth in one list of causes of increased average daily attendance over the past several decades, other causés being such things as "more interesting educational programs," "better prepared teachers," and "increasing interest on the part of parents." Id. c. 3 , at 3 .

${ }^{3} 347$ U:S. 483 (1954). 
or fail to enforce them. In any event, the idea of compulsory education is in some states of this country apt to be put to a testing as severe as that encountered when it was a novel social experiment. In many parts of the world, furthermore, such as India, Burma, Spain, that is exactly what it now is. Largely because of this the XIVth International Conference on Public Education, convened jointly by UNESCO and the International Bureau of Education at Geneva in 195r, had as its main topic of deliberation that of extension of compulsory education and raising of the schoolleaving age. ${ }^{4}$ With these matters UNESCO had a particular concern because of its interest in making the right to education, laid down in Article 26 of the Universal Declaration of Human Rights, ${ }^{5}$ more generally effectual. The Conference was intended, indeed, as an initial step in a long term campaign by the convening organizations in favor of compulsory education.

So perhaps there is something to be accomplished by a consideration of the statutes, enacted now in every jurisdiction in the United States, through whose requirements of attendance the sanction of the law is brought to bear to make education "compulsory."

II

As is usual when legislation reflects and implements basic judgments of the people on affairs which affect their lives intimately, the compulsory attendance laws now on our statute books are the product of a gradual evolution in social concepts following upon changing economic and social conditions. Characteristically, though there is now a surprising amount of uniformity in the laws of the various states and though this has been attained by generally similar stages from state to state, the rate of development was uneven. The first compulsory attendance law was enacted in Massachusetts in 1852 ; by 1896 they were usual in the northern and northwestern states; while in the south they came late, the Mississippi law of 1918 being the last enacted.

Almost everywhere the first step in the process was compulsory education of a type which had nothing to do with attendance. In this initial stage-the date and duration of which varied widely in the different states-it was the establishment and maintenance of free schools which was compulsory. Attendance was voluntary. Sometimes the mandate was issued by the legislature to the local units, notable examples of which are the early colonial laws of Massachusetts, Connecticut, and other of the New England states. ${ }^{6}$ Sometimes the obligation was laid on the legislature by provision of the state constitution, as illustrated by the Virginia provision of $18700^{6^{2}}$

- XIVth International Conference on Public Education: Proceedings and Recommendations (UNESCO, I95I).

${ }^{5}$ Article 26 recognizes the right of every person to education, and stipulates that fundamental and primary education shall be free and that primary education shall in addition be compulsory. The Draft covenant on the Universal Declaration of Human Rights recognizes that "primary cducation shall be compulsory and available free to all."

${ }^{\circ}$ Carlile, Compulsory Attendance Laws in the United States: Historical Background, 4 ED. LAW AND ADMr. 35 (1936).

${ }^{82}$ VA. CONST. Art. VIII, \$3 (1870). 
As might have been expected, so long as attendance remained voluntary the victory won in the establishment of free schools was relatively an empty one. The indifference of parents, the natural disinclination of children toward schooling, the lack of adequate school facilities, the low general standard of living all militated against advantage being taken by many of the opportunity which lay free at hand. Naturally the advocates of education pressed for enactment of laws compelling attendance. In retrospect we may wonder that such laws were so long in coming. Massachusetts had "compulsory education" of a sort for some 200 years before it had "compulsory attendance," and the time was almost equally long in the other New England states, in Pennsylvania, and in New York. Though the process was accelerated in the states which were late in adopting a system of free schools, such schools existed in Virginia for nearly forty years before her laws required anyone to attend them.

It is claimed that Horace Mann was instrumental in persuading the thrifty legislators of the Bay State to enact that state's pioneer act by pointing out the demonstrable waste of public funds involved in operating schools attended irregularly by a small part of the child population when many times the return on the same money could be obtained by making all attend. ${ }^{7}$ But this seems hardly probable, for generally at first in this country the school authorities had all they could do to take care of those who wanted to go to school, without bothering their heads about those who preferred not to. ${ }^{8}$ The fact is that passage of compulsory attendance legislation in any particular state had to wait until the rising standard of living made parents willing to forego putting their children early to work and until improved economic conditions made it possible to finance the great outlays of public moneys needed to build and maintain the necessary plants and teaching staffs. Lack of funds is even now recognized to be the greatest obstacle to full implementation and enforcement of compulsory education. ${ }^{9}$ Anyone who wishes to gain from a contemporary example an appreciation of the difficulties which delayed compulsory attendance legislation in this country will profit by study of the great debate that prevailed in England after the close of the last war over the relatively simple matter of implementing a previous decision of Parliament to raise the school-leaving age from 14 to 15 . Lack of buildings to accommodate the additional students, an acute shortage of teachers, dire need for every available hand to augment the labor force, the great financial difficulties in which the government found itself-all these pressed acutely and dictated delay. The decision of the government to go ahead with this "bold enterprise" in the face of these obstacles is described as "bravely taken." But it is admitted that in 1946 the whole attitude of the English people supported the government's action, whereas the cautious British legislators of r870 who decided

${ }^{7}$ Boykin, Compulsory Education, 20 CASE and Comment 237 (1913).

- Schod Census, Compulsory Education, Child Labor, U.S. Office of Education Bull. 1945, No. 1 .

- Xivth International Conference on Public Educatton: Proceedings and Recommendations (International Bureau of Education Pub. No. 135) 97 (UNESCO, I95 I); Compulsory Educatton and Its Prolongation 28 (UNESCO, I95I). 
to establish compulsory attendance as local school boards should decree, thus giving time for the necessary schools to be built, were confronted by an attitude of hostility or apathy on the part of many. ${ }^{10}$ Similar public sentiment and similar financial problems operated as a deterrent to legislation in this country as well as in England.

Of course no miracle was wrought merely by passage of the compulsory attendance laws. The same economic and social forces which delayed their enactment also hindered their effective enforcement. In his report for the year $1886-87$ (when I7 states and 7 territories had made schooling obligatory) the United States Commissioner of Education reported that "in many instances, however, the compulsory attendance law, if not actually a dead letter, is practically so."11 And in his report for $1885-86^{12}$ he thus described the effect of the New York statute:

The aggregate attendance upon the common schools of the State does not increase in proportion to the growth of the population, notwithstanding the compulsory education act. Many plausible reasons are assigned, the principal being that the school trustees, serving without pay, are loath to enforce the law, and that the buildings now in use are already quite full, in the majority of cases no accommodations existing for more scholars.

When this was written New York had had a compulsory attendance law for better than thirty years. Few other states could boast that their laws were more effective; enactment of the legislation simply came before public opinion or economic conditions permitted hope of full enforcement.

The final stage in the development to our present favorable position has been one of consolidating gains and of moving forward along established lines. This forward movement has been first in the direction of improving the rates of enrollment and attendance, and has been accomplished partly, but only partly, by more efficient enforcement of the attendance laws. Here the improvement has been gratifyingly steady. In 1870 only 57 per cent of the children between the ages of 5-17 were enrolled in the public schools. By 1900 the figure was 72 per cent, and in I950 it had reached 81.6 per cent, with most of the rest enrolled at and attending private schools, as previously pointed out. In the same period the average daily attendance figure climbed from 59.3 per cent to the then all time high of $88.7^{18}$ The second direction of movement, accomplished by definite revisions of the attendance laws, has been toward a greatly increased total period of compulsory schooling. For one thing, the length of the annual school session has been made progressively greater. In 1870 the average number of days schools were in session was 132.2. Today the figure stands at I77.9. ${ }^{14}$ In the second place, the school-leaving age has been moved up generally to 16 , is now 17 in 3 states, and in Nevada, Ohio, Oklahoma,

\footnotetext{
${ }^{10}$ Studies on Compulsory Education, No. 6, W. O. Lester Smith, Compulsory Education in ENGLAND (UNESCO, I95I).

${ }^{12}$ Pupil Personnel Services as a Function of State Departments of Education: Part I, Computsory School Attendance, the School Census, and Child Labor, U. S. Office of Educ. Bull. I940, No. 6, MoNOGRapH 5, at 5.

12 Id. at 5-6.

${ }^{13}$ Statistical Abstract of the United States, 1953 108 el seq.

It Ibid.
} 
and Utah stands at $x 8$, which is the highest attendance age fixed by law in any country. This increase in the total period of schooling, and particularly the raising of the age at which attendance becomes voluntary, has created problems for the professional educator which lie outside the scope of this discussion. It has also raised problems in connection with enforcement of the attendance laws as will be noticed later.

\section{III}

Anyone who studies the compulsory attendance laws of the 48 states is bound to be struck by their similarity in general over-all pattern despite numerous differences of detail. Uniformly they set minimum and maximum ages between which attendance at school is required; impose a legal obligation upon parents and guardians to have their children in regular attendance; provide penalties for non-compliance and procedures for enforcement; and list certain exempted classes of whom attendance is not exacted.

The constitutionality of these laws has been frequently assailed. Yet no court in this country has ever held it beyond the competence of the state to require that children be exposed to a certain amount of instruction, nor has any court denied the power of the state to make reasonable provision as to the type, means, and supervision of such instruction. Thus the basic principles of compulsory education are as firmly supported by legal precedents as by public opinion.

Of course particular provisions of law or particular administrative applications of the laws have met judicial condemnation when shown to be unreasonable. ${ }^{15}$ As to this, however, a distinction must not be lost sight of. In a great many of the cases in which litigation under the attendance laws has reached the appellate courts, it is not the reasonableness of any provision of those laws which is in issue but the reasonableness of some other school regulation. Law or practice, for example, requires vaccination or saluting the flag. If the parents do not believe in vaccination or saluting the chances are that their children will be excluded from classes because they are not proof against smallpox or will not show what is thought to be due respect to the flag. The attendance laws are invoked, the parents haled to court, and the decision is that they are or are not guilty of violating the statutory requirement that they have their children in school. The parents' obligation, as the English decisions hold, ${ }^{18}$ is to have the child attend in such circumstances that he cannot lawfully be excluded from school. But the real question decided is obviously whether for failure to obey the regulation involved the child can lawfully be excluded, and this depends on the reasonableness of it. Such cases lie outside the scope of this discussion.

When one comes to consider in detail the operation of the compulsory attendance laws and the judicial attitude toward their provisions, it is much simpler to start with what these laws do not require than to say what they compel; for the manda(1902).

${ }^{25}$ Pierce v. Society of Sisters, 268 U.S. 510 (I925); State v. Jackson, 7x N.H. 552, 53 Atl. I02I

${ }_{10}$ The point is discussed, with citation of cases, in $86 \mathrm{~J}$. P. 50 (1922). 
tory provisions are severely qualified by "excepts" and "buts" and "unlesses." When the law of any particular state is read and its exemptions duly noted, the first impression is bound to be that most of the teeth have been drawn. There are other reasons for going at the matter in this fashion of looking at the laws in the light of their exemptions. Most of the cases where their validity comes directly in issue involve a parent's claim that his child is in an excepted class, or that the law is invalid because it unreasonably fails to except such class. Moreover, the exemptions allowed by the different states, though protean in detail, can be classified into general types which apply almost universally and thus permit a somewhat systematic treatment. What, then, are the major exemptions?

\section{A. Attendance at Private or Parochial Schools}

Since the decision of the Supreme Court in Pierce v. Society of Sisters ${ }^{17}$ there is no longer need to debate whether a state may deny a parent the right to send his child to a private or denominational school. The court, speaking through Mr. Justice McReynolds, settled the question against the claim of state power. The act struck down was an initiative measure adopted by the voters of Oregon in 1922 requiring parents and others having control of children of certain ages to send them to the public primary schools of the state, unless certain exemptions applied. There was no exemption in favor of private or parochial schools. The case is at times considered as establishing only certain principles of religious freedom; but the decision is broader. Co-plaintiff with the Society of Sisters in the successful effort to enjoin enforcement of the law was Hill Military Academy, a private non-denominational school. The decision protected the charter and property rights of these private institutions; but the fundamental question at issue was the reasonableness of the restraint which the law put on the parent's right to determine how his child should be educated. It was argued on behalf of the state ${ }^{18}$ that as to minors the state stands in the position of parens patriae and "may exercise unlimited supervision and control over their contracts, occupation and conduct, and the liberty and right of those who assume to deal with them." But the Court thought it "entirely plain that the Act of $\mathrm{I} 922$ unreasonably interferes with the liberty of parents and guardians to direct the upbringing and education of children under their control ..." and that "the fundamental theory of liberty upon which all governments in this Union repose excludes any general power of the State to standardize its children by forcing them to accept instruction from public teachers only. The child is not the mere creature of the State; those who nurture him and direct his destiny have the right, coupled with the high duty, to recognize and prepare him for additional obligations."19

No state has made bold, directly or by indirection, to challenge this decision. In fact, the Oregon law aimed at non-public schools was unusual. The attendance statutes of most states at the time it was adopted expressly recognized the right

${ }^{2 \pi} 268$ U.S. 5 IO (1925).

${ }^{19}$ Id. at 534,535 . 
of parents to educate their children in non-public schools, and in this respect have not been altered. Some statutes direct attendance at public or at private school; ${ }^{20}$ others allow attendance at private school as an exception to the general requirement of attendance at the public schools. ${ }^{21}$ But the result, except possibly for administrative details, is of course the same.

State prohibition of attendance at private or parochial schools is one thing. State accreditation and regulation of the instruction given in such schools is another. In the Pierce case the court significantly declared that "No question is raised concerning the power of the State reasonably to regulate all schools, to inspect, supervise and examine them, their teachers and pupils. ..."22 The fair purport of this language is that the states have these powers. In any event they have, to an increasing degree, ${ }^{23}$ presumed to exercise them. Reports of enrollment and attendance are required, ${ }^{24}$ teachers must meet state standards, ${ }^{25}$ and courses and terms of study must be equal to those provided by public schools. ${ }^{26}$ With all this little fault can be found, so long as the regulations are in good faith intended and administered to make sure attendance at private school is not made the means of avoiding the state's legitimate concern for the adequate education of its children.

\section{B. Instruction Outside School}

Must children be sent to school-whether public or private-or may a parent instruct his child at home or procure private tutoring? If private instruction is a right not to be denied those who wish to assert it, how far may the state go in regulating and supervising it? Here is the point where the state's exercise of power is apt to collide most directly with strongly held claims of parental right. The cases are not many, and the parents who bring them into court may be considered eccentric by most people. But the issue they raise is the fundamental one-namely, what is the public interest served by compulsory education which justifies overriding the parent's recognized right to control his children?

To judge by the cases, it is probably a supportable proposition that this interest

${ }^{20}$ E.g., Miss. Code $\$ 6509$ (1942); INd. STAT. ANN. \$28-505 (1933).

11 E.g., Cazifornia Educ. Code $\$ 516601$ and I6624.

${ }^{23} 268$ U.S. 510, at 534 .

${ }^{23}$ School Census, Compulsory Education, Child Labor, U.S. Office of Educ. Bull. 1945, No. I, at 24 .

2t In Maryland, for example, private schools must be open for inspection by the state educational authorities "at all reasonable times" and must furnish such information and reports as the state superintendent of schools shall deem proper. Mo. Cone Art. 77, $\$ 20$ (x95I). In Minnesota there is a specific statutory duty to make reports containing the same information as is required respecting public schools. Minn. Stat. ANN. \$r32.07 (I945).

${ }^{25}$ In Minnesota a school, to satisfy requirements of compulsory attendance, must be one where all the common branches are taught "by teachers whose qualifications are essentially equivalent to the minimum standards for public school teachers of the same grades or subjects." MinN. STAT. ANN. §I32.05 (1945).

${ }_{20}$ Massachusetts, for instance, allows the local school committees to approve private schools for attendance purposes but "only when the instruction in all the studies required by law is in English, and when satisfied that such instruction equals in thoroughness and efficiency, and in the progress made therein, that in the public schools in the same town. ..." ANN. Laws Mass. c. 76, \$r (1953). And see Maine Rev. Stat. c. 37, \$3 (1944); Ill. Rev. Stat. c. I22, \$26-I. 
is not so much the welfare of the individual child as the welfare of the body politic. This idea is reflected in the declaration of the Ordinance of 1787 that: "Religion, morality, and knowledge being necessary to good government and the happiness of mankind, schools and the means of education shall forever be encouraged." It finds early expression in the belief of men like Jefferson that a democracy cannot survive unless the citizenry is literate. The New Hampshire court has given perhaps the clearest judicial statement of this view. In 1902, by way of dictum in a case where it held unreasonable the application of the compulsory attendance law to a child in ill health, this court said: $:^{27}$

That education of the citizen is essential to the stability of the state, is a proposition too plain for discussion. ... The Constitution declares that "knowledge and learning, generally diffused through a community" are essential to the preservation of a free government. ... It thus being the constitutional duty of the legislature to diffuse knowledge and learning through the community, it must be within the constitutional power of the legislature to enforce school attendance to that end.

In a later case this same court stated $:^{28}$

The primary purpose of the maintenance of the common school system is the promotion of the general intelligence of the people constituting the body politic and thereby to increase the usefulness and efficiency of the citizens, upon which the government of society depends. Free schooling furnished by the state is not so much a right granted to pupils as a duty imposed upon them for the public good. If they do not voluntarily attend the schools provided for them, they may be compelled to do so [citing cases]. While most people regard the public schools as the means of great personal advantage to the pupils, the fact is too often overlooked that they are governmental means of protecting the state from the consequences of an ignorant and incompetent citizenship.

It is the natural right of the parent to control the upbringing of his child; it is his natural duty to educate the child. ${ }^{29}$ The controlling interest of the state is the development of a citizenry intelligent enough to maintain our democratic form of government. In furtherance of this interest the free public schools have been established, it being obvious that most parents have not the means-and perhaps not the desire- to educate their children otherwise than at free schools. But does the state's interest demand that the child be educated in school; can the parent's duty be discharged only by sending his child to school, or is the state's need met and the parent's obligation discharged so long as the child receives, in whatever fashion the parent directs, a certain amount of instruction? What interest has the state in the means or method through which this instruction is given?

It is the legislative judgment in most jurisdictions that the public interest stops short of the requirement that children be educated at a school. The statutes of the great majority of the states recognize expressly the propriety of private instruction.

${ }^{27}$ State v. Jackson, 7x N.H. 552, 553, 53 Atl. x02I, 1022 (x902).

${ }^{28}$ Fogg v. Board of Education, 76 N.H. 296, 299, 82 Atl. 173-174 (1912).

${ }^{28}$ See Meyer v. Nebraska, 262 U.S. 390, 400 (1922); People v. Levinsen, 404 Ill. 574, 577, 90 N.E. $2 d 213,215$ (1950). 
In these states the concern is to assure that if instruction is privately. given it not be inferior in content to that available in the public schools.

Thus the New York law stipulates ${ }^{30}$ that "Instruction may be given only by a competent teacher. ... Instruction given to a minor elsewhere than at a public school shall be at least substantially equivalent to the instruction given to minors of like age and attainments at the public schools of the city or district where the minor resides." In the case of People $v$. Turner, ${ }^{31}$ decided in the New York Appellate Division in 1950, where parents were being prosecuted for non-compliance with the attendance laws, the issue was whether error had been committed by the trial court in refusing to allow evidence of Mrs. Turner's competence to teach her children, though she had not been certified by the Commissioner of Education. The statute contained no requirement of such certification. The court decided that error had been committed. The reasoning is most illuminating: $:^{32}$

The object of a compulsory education law is to see that children are not left in ignorance, that from some source they will receive instruction that will fit them for their place in society. Provided the instruction given is adequate and the sole purpose of nonattendance at school is not to evade the statute, instruction given to a child at home by its parent, who is competent to teach, should satisfy the requirements of the compulsory education law.

In Oklahoma the law demands attendance at public school "unless other means of education are provided." The Oklahoma court in Wright $v$. State ${ }^{\mathbf{3 3}}$ decided that on the facts children were being given efficient instruction at home by their parents, and that, absent statutory provision, private teachers did not have to have the same qualifications as teachers in the public schools. For many years the requirement in England has been attendance at a public day school unless the child is under efficient instruction in some other manner. In Bevan v. Shears ${ }^{34}$ it appeared that the father became irritated at the punishment given his son at public school, withdrew the child, and employed a private tutor for him. He was prosecuted for violation of the attendance law and it was urged that the instruction was not "efficient" because not in the same subjects offered in the public school. Lord Alverstone held, however, that absent laws requiring instruction in particular subjects "it cannot be said that as to a particular child there is a particular standard of education by which the child must be taught ... therefore the justices have to decide whether in their opinion the child is being taught efficiently so far as that particular child is concerned."35 One of the other justices observed wryly that if the Crown's argument were valid the instruction at Eton would probably not qualify as sufficient. It should be noted, however, that the English courts and public in general have given more respect to the parent's desires regarding his children's education than has been the case in this country.

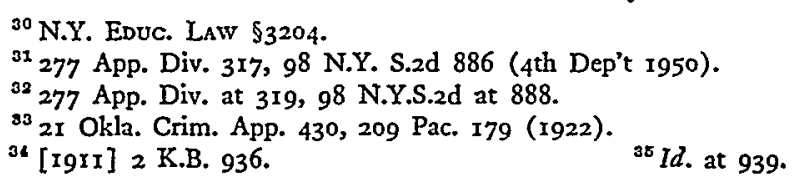


As early as 1893 the Massachusetts court declared" that "The great object of these provisions [requiring attendance] of the statutes has been that all children shall be educated, not that they shall be educated in any particular way." The case itself may not be direct authority for the proposition that a parent may educate his child privately, for Roberts had sent his daughter to a school not approved by the state authorities; but the statement quoted clearly shows the judicial attitude in opposition to the idea that the state may force attendance at school.

Such judicial viewpoint is perhaps most clearly demonstrated in two cases decided respectively in Indiana and Illinois. The statutes of both states require attendance at a public or private school and make no exception in favor of equivalent instruction otherwise given. Yet the holding in Indiana ${ }^{37}$ was that a father who sent his child to a teacher formerly employed in the public schools who instructed her in the subjects there taught had complied with the compulsory attendance laws requiring attendance at public, private, or parochial schools; and this even though the teacher neither had nor sought other pupils and did not advertise as a school. The court was of the opinion that the law had nothing "to do with the way or place where a child shall be educated" and said that the purpose of the compulsory attendance law was to secure to the child the opportunity to acquire an education which the best interests of the child and of society demand. "The result to be obtained and not the means or manner of attaining it, was the goal which the lawmakers were attempting to reach." ${ }^{38}$ In the recent Illinois case ${ }^{30}$ the court held that a child instructed at home by her mother was attending a "private school" within the intent of the compulsory attendance law. The object of such laws, in the opinion of the court, "is that all children shall be educated, not that they shall be educated in any particular manner or place."40

Such appears to be the prevailing legislative and judicial view. There is another view, however, under which the state is justified in precluding private instruction. The New Hampshire court allows such restrictive provision on the ground that the state is entitled to supervise education however given, and that it is not administratively feasible to supervise home instruction or private tutoring. ${ }^{41}$ The case arose in 1929 under the New Hampshire law requiring attendance at public school or an approved private school. Hoyt, charged with violation of this law, unsuccessfully defended on the ground that his children were taught at home by a tutor. The court thought that: ${ }^{42}$

If the parent undertakes to make use of units of education so small, or facilities of such doubtful quality that supervision thereof would impose an unreasonable burden upon the state, he offends against the reasonable provisions for schools which can be supervised

${ }^{38}$ Commonwealth v. Roberts, I59 Mass. 372, 374, 34 N.E. 402, 403 (I893).

s7 State v. Peterman, 32 Ind. App. 665, 70 N.E. 550 (1904).

${ }^{38} 32$ Ind. App. at $67 \mathrm{I}, 70$ N.E. at 552 .

${ }^{30}$ People v. Levinsen, 404 Ill. 574, 90 N.E.2d 213 (1950). This holding is criticized in Note, 18 U. OF CHI. L. REV. 105 (1950).

${ }^{10} 404$ Ill. at 577,90 N.E.2d at 215 .

${ }^{41}$ State v. Hoyt, 84 N. H. 38 , I 46 Atl. I70 (1929).

$484 \mathrm{~N}$. H. at $40,4 \mathrm{I}, \mathrm{I} 46 \mathrm{Atl}$. at $\mathrm{I} 7 \mathrm{I}, \mathrm{I} 72$. 
without unreasonable expense. The state may require, not only that education facilities be supplied; but also that they be so supplied that the facts in relation thereto can be ascertained, and proper direction thereof maintained, without unreasonable cost to the state. Anything less than this would take from the state all-efficient authority to regulate the education of the prospective voting population. ... [T] [Te state is entitled to establish a system whereby it can be known, by reasonable means, that the required teaching is being done.

Two lower courts in New Jersey have expressed the opinion that in the conditions of modern life instruction at home or by a private tutor lacks certain qualities essential to the development of the needed attributes of citizenship. The New Jersey law ${ }^{43}$ requires attendance at public or private school or "equivalent instruction elsewhere than at school." The precise holdings in the cases actually were that instruction given by parents was not "equivalent." The significant thing, however, is that in the earlier case it was said and in the later case held that such instruction could not be equivalent-thus in effect setting at naught the legislative determination to the contrary.

The first case was decided by the Juvenile and Domestic Relations Court, Essex County, in $1937 .^{44} \mathrm{Mr}$. and Mrs. Bongart, who were attempting to educate their children at home, were held to be "disorderly persons" and fined for non-compliance with the compulsory attendance statute because the court found they were not qualified to teach and were not giving their children adequate instruction. However the court went on to philosophize:

A primary objective of education today is the development of character and good citizenship. Education must impart to the child the way to live. This brings me to the belief that, in a cosmopolitan area such as we live in, with all the complexities of life, and our reliance upon others to carry out the functions of education, it is almost impossible for a child to be adequately taught in his home. I cannot conceive how a child can receive in the home instruction and experiences in group activities and in social outlook in any manner or form comparable to that provided in the public school. To give him less than that is depriving the child of the training and development of the most necessary emotions and instincts of life.

In $195^{\circ}$ the Cape May County Court, in a case ${ }^{45}$ where the facts were quite on a par with those in the Bongart case, held flatly that where children are instructed at home the "entire lack of free association with other children ... which is afforded them at public school" prevented their receiving education that was equivalent.

There is no decision of the Federal Supreme Court on the point; but when and if some parent brings his case there, counsel will undoubtedly point to the ambiguous dictum in Meyer $v$. Nebraska" that "The power of the State to compel attendance at some school and to make reasonable regulations for all schools . . . is not questioned." I do not care to hazard a guess whether the Court will adhere

\footnotetext{
${ }^{13}$ N. J. StAT. ANn. \$I8:14-14.

"Stephens v. Bongart, 15 N.J. Misc. 80, 92, 189 Atl. 131, 137 (1937).

${ }^{45}$ Knox v. O'Brien, 7 N.J. Super. $608,614,72$ A.2d 389, 392 (1950).

${ }^{10} 262$ U.S. 390,402 (1923).
} 
to the prevailing view upholding the parent's right to instruct his own child or adopt the position of those few states and courts denying that right. The decision, when it comes, may not be of great practical moment. Yet I feel sure that an invisible attendant upon the Court on the day of its reading will be the spirit of the Texas Superintendent of Education who in I8go expressed the firm conviction that compulsory education was "perilous to one of the most vital and essential of the institutions on which civilization rests-the family."

One thing more needs to be said. Most states which permit private instruction assume to regulate it to some extent. As indicated above, the requirement that such instruction be equivalent to public instruction is quite common, as is the requirement that the private tutor, whether parent or not, should either be certified by or meet qualification standards set by state authorities. ${ }^{48}$ I should think little question could be entertained as to the validity and wisdom of such regulation.

\section{Mental or Physical Unfitness}

So far as statutory provisions go, it is a safe generalization to say that in nearly all the states ${ }^{49}$ mental or physical disability incapacitating the child for school work is expressly recognized to confer exemption from compulsory attendance. The New York law, to take an example, says that a minor "shall be required to attend upon instruction only if in proper mental and physical condition." "5o

Such exemption is obviously proper in many cases; yet just as obviously it opens a rather wide loophole which some parents may make use of to avoid their duty under the school laws. How wide the loophole is in any state depends pretty much on administrative practices. New York has rather elaborate provisions to prevent abuse. Only qualified examiners approved by the State Education Department can decide that a child is unfit or incapable of attending school or of profiting from instruction. Two such examiners must concur, their finding must be reported to the State Department, and exemption can be granted for not more than one year. But in the opinion of one qualified observer, the New York law is rather ineffective because of lax enforcement. ${ }^{51}$ In most other states the machinery of enforcement is less detailed, decision as to fitness being made either by the local school board or by the division superintendent on the certificate of any doctor qualified to practice. Most such cases, I suspect, are actually decided in the first instance by the local attendance officer.

${ }^{17}$ Oscar $\mathrm{H}$. Cooper, in an address before the National Educational Association in 1890, as reported in U. S. Office of Education Bull. 1940 No. 6, Monograph No. 5, at 6.

${ }^{4}$ Rice v. Commonwealth, I88 Va. 224, 49 S.E.2d 342 (1948), holding valid a statutory provision that a private tutor meet qualifications set by the State Board of Education; People v. Turner, 263 P.2d 685 (Cal. App. I953). The latter case involved the same unfortunate-or intransigent-parents who successfully asserted their rights in New York. See supra note 31 . In California they were less successful because the state required private instructors to be certified by the public authorities. Their tribulations are fully detailed in the Nov. 13, 1953 issue of Colliers Magazine, pp. 62-68.

10 The Georgia statute has no such express exemption.

${ }^{50}$ N.Y. EDuc. LAw $\$ 3208$.

52 Van Auken, School Exemptions in New York State, American School Board Journal, April, 1951, p. 36 . 
In 8 or 9 states this general exemption granted on the ground of mental or physical disability is narrowed somewhat by specific provisions requiring blind and deaf children to receive special instruction. ${ }^{52}$ Often the law provides for training at special state schools, ${ }^{53}$ though some states allow private education of children so handicapped. ${ }^{54}$ The North Dakota statutes apply to the feebleminded as well as to deaf and blind children. ${ }^{55}$ Pennsylvania makes special provision for education of the physically and mentally handicapped. ${ }^{56}$

Much more important, however, is the establishment in recent years by local school boards (chiefly in the cities) of special schools or special classes for the instruction of handicapped children, such as the blind and partially seeing, the deaf and hard-of-hearing, the crippled, the mentally retarded, the socially and emotionally maladjusted, those with speech defects, and those with special health problems. In $195^{2-53}$ special classes or schools for one or more of these types of disabled children were conducted in all the states, in some 1,785 different localities, with a total enrollment of 474,300 pupils. By far the greater number of these children, it is true, were in classes for those mentally retarded or suffering from speech defects; but in 45 states classes were conducted for crippled children, in 46 states for those hard-ofhearing, and in 40 for those with special health problems. ${ }^{57}$

Now the effect of this on the statutory exemption from attendance of children mentally or physically unfit for instruction is not hard to see. Though a child is handicapped, if the schools offer classes specially designed for his training, that child is not "disabled" or "incapacitated" within the intent of the attendance law. And so it has been held.

A decision touching on this point was reached relatively early in Wisconsin. ${ }^{58}$ The local school board established a special school for deaf children and those with defective speech. One Beattie's son, though normal mentally, had suffered from birth a form of paralysis which affected his vocal chords. When this child was placed in the special school, Beattie sought unsuccessfully to mandamus the school board to permit his reentry at the public general school. Admittedly the decision is not as satisfactory as it might be on the point under discussion, because as the case came up the court did not pass on the local board's right to force the child's attendance at the special school, but rather on its right to deny him instruction at the general school. And as to this the decision was put on the footing that the presence of this child in class was harmful to the general student body. ${ }^{59}$

In Iowa the question has been directly decided that a local board may establish

${ }^{82}$ E.g., Neb. Rev. Stat. \$79-204 (I943).

Es IowA Code ANn. \$299.r 8 (1946).

U TENN. CODE ANN. \$2445 (I934).

EE N.D. CODE $\$ 15-3402$ ( 9943 ).

"Pa. STAT. ANn. §I3-1371 et seq.

${ }^{87}$ Biennial SuRvey of Education in the United States 1952-I954, c. 5, Statistics of Special Education for Exceptional Children, 1952-53 (U.S. Office of Education, 1954).

${ }^{68}$ State ex rel. Beattie v. Board of Education, I69 Wis. 231, I72 N.W. 153 (x919).

69 There can be little question as to the propriety or the legality of exclusion in such circumstances, if only administrative discretion is not abused. 
ungraded schools for backward children and require attendance at them of such children. ${ }^{60}$ And it has been so determined in England. ${ }^{61}$

\section{Distance from School}

A number of states excuse from attendance children of stated ages who live more than stated distances from a public school and from a means of public transportation. This has been a ground of exemption in England since education first became compulsory in 1870 . Since another paper in this symposium is concerned with transportation of pupils, no more will be said of it here.

\section{E. Age and Satisfaction of Minimum Education Requirement}

We are so accustomed to our tots entering upon school at 6 that it may not be known to many that in only 3 states $^{62}$ must they be sent from home so early. The English have from the start set the going-off age at 5. With us to the contrary the usual minimum age of compulsory attendance is 7 -this being the provision in $3^{6}$ states. In the remaining 9 jurisdictions, the figure is set at $8 .^{63}$

As previously indicated, ${ }^{64}$ the maximum age varies from $\mathrm{I} 6$ (in $4^{\mathrm{I}}$ states) to 17 and 18. And except for the matter of employment, which will be noticed later, the important thing really is not what is the minimum or the maximum age, but how much time lies between the two.

In most states that cannot be determined simply by taking the minimum age from the maximum; for in all but 9 jurisdictions the child can leave school at an earlier age if he has completed a specified course of study. As of r950 in nearly half the states-in $2 I$ to be exact-this was the elementary course, meaning usually 8 grades. In 15 others, completion of high school was required to justify nonattendance by a child under the normal leaving age. ${ }^{65}$

As a general proposition, therefore, the laws are not designed to require attendance at school up to a certain age. The object'seems to be that children shall acquire, or at least be exposed to the chance to acquire, a certain amount of knowledge. If the child is bright enough to run this course quickly, well and good. If he is dull he will be kept at the task until the maximum legal age, ${ }^{66}$ and then excused from attendance however little he has learned.

\section{F. Work Permits}

The inter-relationship between compulsory education and child labor legislation is not only a fact, but an inevitable fact. It has been said that "laws to prevent children from working and laws to secure their attendance at school are answers

${ }^{80}$ State v. Ghrist, 222 Iowa 1069, 270 N.W. 376 (1936).

${ }^{61}$ Woodward v. Oldfield, [I928] I K.B. 204. Compare with London County Council v. Maher, [I929] 2 K.B. 97, where under the special circumstances of the case a parent whose child was deaf was held to have a reasonable excuse for not sending it to a residential school for such children.

${ }^{82}$ Michigan, New Mexico, and Ohio, as of 1950. U.S. Office of Education Circurar 278 (1950).

${ }^{03}$ Ibid. Supra p. 6.

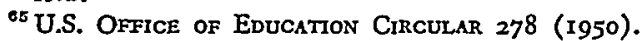

${ }^{66}$ In some states, such as Ohio, the statutes allow carlier school-leaving upon a determination that the child is incapable of profiting substantially by further instruction. OHIO CODE \$3321.03 (1953). 
to two sides of the same question, namely, child welfare."67 The opinion of the International Labour Office is that "child labour laws and school attendance regulations supplement one another and form together a network of provisions designed to prevent child labour and to ensure educational opportunity." 68

This is so not only because the enforcement of each set of regulations makes easier and complements the enforcement of the other, but also because the purpose of the child labor laws is to prevent premature employment to permit the child's proper educational development as well as his physical development. ${ }^{69}$ Some of the earliest statutory provisions in this country relating to compulsory education prescribed the inclusion in apprenticeship contracts of clauses requiring the master to afford certain instruction to indentured children. ${ }^{70}$ Long before general school attendance was made compulsory the early child labor laws contained provisions relative to the education of working children. The British Factory Act of r8 33 required children to have a certificate-called a "schoolmaster's ticket"-stating they were receiving a prescribed minimum of instruction amounting to two hours of attendance at school a day. ${ }^{71}$ In the child labor legislation of this country, of the period before 1850 , manufacturers who employed children were required to provide education for them. ${ }^{72}$ In England one of the potent arguments used by the proponents of the orginal Education Act of 1870 was the precedent as to compulsory education established by the various factory acts under which some 85,000 children were then receiving part-time schooling under a compulsory system. ${ }^{\mathbf{7 3}}$ It cannot be doubted that the educational provisions of our early child labor laws also helped prepare public opinion for acceptance of compulsory attendance laws.

Here is not the time or place, however, to detail the statutory provisions which interlink the child labor and school attendance legislation of the different states. ${ }^{74}$ A summary statement will do for present purposes.

It should be noted to begin with that everywhere the school-leaving age is set as high as or higher than the minimum age for employment. Hence there is little danger in this country of a child leaving school and loitering on the streets until he becomes employable; though this situation theoretically would be possible in some states if a child should finish elementary school training before he attained the minimum age set by the child labor law. The real problem is how to regulate employment of children who are over the minimum age for employment but under the

${ }^{07}$ U.S. Office of Education Buli. 1940, No. 6, Monograph No. 5, at 6.

${ }^{68}$ Studies on Compulsory Education, No. 5, Child Labour in Relation to Compulsory EducaTION 26 (UNESCO I95I).

${ }^{\circ D}$ Id. at 19.

${ }^{70}$ Carlile, Compulsory Attendance Laws in the United States: Historical Background, 4 ED. LAW AND AdMr. 35 (I936).

${ }^{71}$ Henry R. Adam, The Education of Children Engaged in Industrx, I833-1876 30 et seq. (I93I).

72 Children and Young Persons under Labour Law, International Labor Office Studies and Reports, Series I, No. 3 (I935).

${ }^{73}$ Studies on Compulsory Education, No. 6, W. O. Lester Smith, Compulsory Educatton in ENGLAND I4 (UNESCO I95I).

7t They were summarized in 1952 in State Child Labor Standards, U.S. Dep't of Labor Bulz. 158. 
school-leaving age and who either are excused from further attendance on completion of the required course or whose individual situations or family financial position make it advisable that they be excused from further attendance at school.

The regulatory device universally used to handle such cases is the work permit or employment certificate. Employment of minors under the school-leaving age who have not been issued such permits is made a penal offense under the child labor laws. Being at work under such permit is accepted as an excuse for non-attendance at school, and this is often spelled out as an express exemption ${ }^{75}$ along with mental and physical disability and the other things noticed above. Children working under such permits frequently are required by law to attend continuation classes of some sort $^{76}$ and in some states the law makes it mandatory upon the local school authorities to establish continuation schools where a certain number of children have been issued work permits. ${ }^{77}$ Permits may also be issued for vacation work and for occupation out of school hours. In the great majority of the states the authority to issue permits is vested in the local school officials, usually the superintendent, of schools. The precise conditions on which they can be issued vary, but almost everywhere there is required (a); satisfactory proof of age, (b) school record, and possibly proof of completion of a certain level of work, ${ }^{78}$ (c) physician's certificate of physical fitness, and (d) employer's written statement that work is available and description of its nature. As a general thing the child's parent or guardian must appear with him to apply for a permit, and there may be required a showing of economic necessity. ${ }^{70}$

All of this may seem a considerable and inadvisable undercutting of the salutary provisions for keeping children at school. Yet we have not come to the place where poverty has vanished. There is a great deal of truth in the statement of the International Labour Office ${ }^{80}$ that "where children are compelled to work in order to support themselves or their family, economic necessities appear to be stronger than any regulation for keeping them out of employment and in school."

Nor have judges been unaware of this fact of life. It was presented to the English court in one of the first cases to reach it under that country's compulsory education act, in the case of London School Board v. Duggan. ${ }^{81}$ It appeared that Duggan was a laborer at small wages, and evidently could not earn more than he did; nor did he or his wife waste money on drink or in other unnecessary, if pleasant, ways. His eldest child, a girl of twelve years and the eldest of seven children, was put out as a nursery maid at three shillings a week. Her wages she

${ }^{75}$ ILL. ANN. Stat. c. $222, \$ 26-$ I.

${ }^{70}$ Id.; Cal. Education Code $\$ 17001$.

77 Among the states making establishment of continuation schools or classes mandatory upon the local authorities (usually when a certain number of work permits have been issued) are Arizona, Delaware, and California.

${ }^{78}$ E.g., OHro CODE $\$ 3331.01$ (1953) requires proof that the applicant has satisfactorily "passed a test for the completion of the work of the seventh grade."

${ }^{79}$ Surprisingly few states make this requirement express. Among those that do are Michigan, Tcxas, and New Mexico.

${ }^{80}$ Studies on Compulsory Education, No. 5, Child Labour in Relation to Compulsory EducaTION 22 (UNESCO $\mathrm{r} 95 \mathrm{x}$ ).

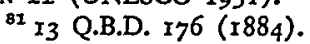


handed her mother and without them it would have been impossible to provide food for the family. In these circumstances Duggan was prosecuted for failure to have the child in school and was held not guilty, on the ground he had a reasonable excuse. Stephen, J., allowed that ${ }^{82}$

She has been discharging the honourable duty of helping her parents, and, for my own part, before I held that these facts did not afford a reasonable excuse for her non-attendance at school, I should require to see the very plainest words to the contrary in the Act.

It might be added that the girl could read fluently and "had been fairly instructed in arithmetic and grammar." As late as $x 933$ it was held by an English court that a parent had a reasonable excuse for not sending her thirteen year old daughter to school where there were nine children, and unless the child stayed at home the mother could not go out to work to support the family. ${ }^{83}$

There are more situations such as that in this country than one likes to admit. Free transportation of pupils, free textbooks, school lunch programs, supply of clothing to needy children, the general welfare services all do much nowadays to relieve the financial pressures upon parents to keep their children from school. But still in many cases it is a question whether over-all more good or harm is done by forcing a child to school until he is $I 6$ when his family desperately needs the wages he could make. The cautious use of work permits is a wise means of affording relief in hardship cases, while maintaining sufficient control to avoid abuses.

\section{IV}

When I and most of those who read this were of an age when the sound of the school bell had little music in it, and the imagined sight of bass breaking water in the pond laid temptation heavy on us, the truant officer was a figure to be reckoned with. He was a fierce minion of the law, a spoil-sport, a creature who had as little of the milk of human kindness in him as the dog-catcher, his delight being to lie in wait and pounce upon the unwary lad bent upon innocent fun.

Today they say all this is changed. The modern counterpart of the fellow who used to chase us is called an attendance officer, and the softer title is significant. $\mathrm{He}$ is still ubiquitous in the sense that he is a recognized official in nearly every state, with statutory powers and duties; he is still on the grass-roots level in the work of enforcing the attendance laws; he still in most places can nab truants on the spot and can enter and inspect places where minors are employed. But the accepted ideas as to what he is supposed to do, and how, have changed greatly. A job content sketch of his work today would show him to be more of a social worker than a policeman. The notion entertained in sterner times that his work consisted

${ }^{82}$ Id. at 177, I78.

sa The case is not reported but is referred to in an article in 97 J.P. 283 (r933) in which the author laments that the rule of London School Board $v$. Duggan should have been applied after a lapse of fifty years. 
of "enforcing the law" has given way to emphasis upon diagnosing the pupil's difficulties and discovering the individual maladjustments and the family and economic conditions which we have come to realize lie at the root of most preventable absences. As long ago as I934 the director of Philadelphia's Division of Compulsory Education wrote that "If the prosecution of parents or the rounding up of vagrant children were the chief business of the attendance service, it might well be turned over in the larger cities to the police. ..." ${ }^{34}$ The thing expected of the attendance officer today is discovery of the causes of absenteeism followed by preventive action. ${ }^{85}$ This may be by way of counseling the child or the family; frequently it involves close collaboration with the welfare agencies, to get clothes or food or medical treatment.

If counsel goes unheeded and preventive efforts do not prevent, what then? That will depend. It will depend on what the law allows in the way of sanction, what the local policy is as to applying it, and perhaps on who is at fault, parent or child-that is whether the parent refuses to send his child or whether the child will not go.

It must be realized that enforcement of the compulsory attendance laws is left for handling at the local level. In all except a few jurisdictions the state departments of education are not charged with responsibility in this field, and have assumed none. ${ }^{86}$ Only in Connecticut, it seems, is enforcement directly the concern of the state department and administered through a division of the department.

What the local policy is therefore comes down usually to a question of the attitude of the local school board, nor is this much changed by the fact that the state's attorney may, as in Virginia, be charged with the duty to prosecute violations of the attendance statutes. He will rarely go counter to the board's policy or trouble himself to prosecute except at its request.

The person who finds himself called on to answer the criminal warrant is almost always the parent. This is so because of a fundamental fact that probably should have been remarked before this: universally the attendance laws accept the premise previously adverted to that it is the natural duty of the parent, guardian or other person having control of a child to educate it. The public schools are at hand for the discharge of this duty, and (absent some applicable exemption) the parent is guilty if he does not cause his child to attend them.

In most cases, to judge from my own experience and what I am told by school administrators, it is the fault of the parent when a child misses many possible attendances-through indifference, because of desire for the benefit of the child's

8* Gideon, Police Duties Are a Small Part of Attendance Work, The Nation's Schools, Sept. r934, pp. $27-28$.

${ }^{85}$ Bentley, Some School Attendance Problems, American School Board Journal, Dec., 1930, p. 36.

${ }^{80}$ U.S. Office of Education Buzl. I940, No. 6, Monograph No. 5, at II-12. The quite common practice of distributing state funds to local districts on the basis of average daily attendance figures, how. ever, has had an understandable effect on the alertness with which local officials encourage attendance. And the almost universally required biennial school census supplies in convenient form the neccssary information against which to check enrollment. 
wages, or because of religious belief or strongly held objection to some school practice. To hold the parent responsible is perfectly fair, and in most cases effective. Yet if the parent is stubborn, the penalties of the law are too slight to have much in terrorem or actual force, the offense being merely a misdemeanor. Consider Mr. Bey, for instance, who for reasons of religious conviction, would not send his children to school on a Friday. Fined in 1943 and again in 1944, he was back before the court in 1950 , as determined as ever. ${ }^{87}$

When the attendance laws were first enacted a man had firmer control over his offspring than most seem to have-or want-today. And it was fair to assume that the compulsion of the law passed pretty quickly down through father to child. Nowadays, however, it happens in many cases that the child is incorrigible, refuses to attend school, and there is little the parent can do about it. Here it would be pointless to punish the parent, and unjust too, unless for letting things come to such a pass in the first place. To take care of this situation it is necessary to operate directly on the child. Many states expressly classify an habitual truant as a delinquent and provide that his case shall be handled through the juvenile courts. ${ }^{88}$ Others give to the local school authorities power to order the child to a special truant school.89

The sensible thing would be, I believe, to provide for a hearing before the juvenile court with the judge authorized to make orders against either parent or child, or against both, as the circumstances might demand. In such a proceeding all angles of the situation could be explored, the real causes of the difficulty brought to light, and compulsion directed where it would be most effective.

\section{$\mathrm{V}$}

The compulsory attendance laws are relatively simple in their terms and express a simple, if important, social concept. They are the tangible expression of the accepted belief that the state has a paramount interest in the education of its citizens, to which interest the claims of parents and their right to control of their children must yield. As to matters of detail there has been, and probably there will be, dispute; as to the central philosophy of such legislation there is no longer question. This being so, the laws claim general public acceptance and operate in a climate of opinion which dictates voluntary compliance. Occasion for enforcement is fortunately rare. If the legal provisions for enforcement are to some extent inadequate and inefficient, the matter is of little practical moment.

All this being obvious, the converse should also be obvious. The laws are now effective because supported strongly by public opinion. Remove that support and they would be ineffective. As the need for enforcement increased, so would the difficulty of enforcement. And under conceivable circumstances the point would

${ }^{87}$ Commonwealth v. Bey, I66 Pa. Super. 136, 70 A.2d 693 (1950).

${ }^{88}$ The list of such states includes Pennsylvania, Virginia, Kansas, and others.

${ }^{80}$ Massachusetts, New York, Iowa, Minnesota, and others. Elsewhere commitment to truant school is by court order, as in Indiana and Kentucky. 
be reached where there would be outright legislative repeal or, more probably, general acquiescence in a policy of non-enforcement rendering the statutes dead.

We speak of compulsory education. But in fact we have voluntary education. The compulsory attendance laws operate and are designed to operate only on a very insignificant minority. If because of changing public opinion education should cease to be voluntary on the part of most, I doubt very much that it could actually be made compulsory, whatever provision the law should make. 